\title{
Teachers' Satisfaction with Collins Curriculum from their Perspective
}

\author{
Mahmoud Ahmad Humaidat \\ Amal Metleb Salman Alsabeelah \\ Banan Abdelrahman Awwad Alkharabsheh \\ Curriculum \& Instructional Technology, \\ Al- Balqa' Applied University, \\ As-Salt, Jordan
}

DOI: https://doi.org/10.36941/jesr-2021-0142

\begin{abstract}
This study aimed to investigate teachers' level of satisfaction with Collins's in Amman Education Directorate. The study sample consisted of (450) teachers from the first and second Amman Education Directorate. A questionnaire of the teachers' degree of satisfaction with Collins curriculum was used to collect data. The results showed that the level of teachers' satisfaction in the primary schools of Amman Directorate of Education with Collins curriculum was average. They also showed that there were statistically significant differences at the level of significance $(\alpha \leq 0.05)$ in the scale of "teachers' satisfaction with Collins curriculum" according to the teachers' experience variable in favor of the experience category from 5-10 years. In contrast, there were no differences in the teachers' satisfaction scale with Collins curriculum according to the gender variable.
\end{abstract}

Keywords: Collins curriculum; Level of satisfaction; Amman Directorate of Education; Jordan

\section{Introduction}

Most countries have sought to develop their curricula and update them to meet the requirements of modern developments to fulfil the aspirations of their nation, as the educational process is a mobile, changing, and developing process, where the more developed countries are keen to identify and address problems and gaps related to their scientific methods. The educational system in Jordan keeps pace with educational developments and cooperates with international organizations such as UNESCO, UNICEF, the United States Agency for International Development, and others to develop education. The Fourth National Conference for Developing Education in Jordan recommended to develop operational proposals to follow new mechanisms in developing curricula and preparing textbooks, based on the experiences of several developed and developing countries such as the United States, Britain, South Korea, and Indonesia which follow the integrated project for preparing textbooks (Ministry of Education, 2017).

The National Curriculum Development Centre for 2019 undertook the tasks of developing the curricula, so it developed the science and mathematics books for the first and fourth grades, adopting 
Collins's approach, as it began to be taught to students within a plan that would build a solid scientific foundation for students within a comprehensive plan with the beginning of the new academic year 2020/2019.

Collins's curriculum goes back to Marva Collins, an American teacher, who in 1975 founded Westside Preparatory School in the United States of America (Collins \& Tamarkin, 1990; Hollins, 1982). She had a specific vision that emphasized that children do not fail, but teachers and school systems fail, and her leadership philosophy viewed that success is achievable for everyone (Collins \& Tamarkin, 1990). She embraced the idea of providing students with high-quality books to encourage thinking at a higher level in them (Lockhart, 2019).

Mathematics curricula are considered one of the most important subjects that help developing students' logical thinking (Barika, 2008) because it depends on the individual's way of thinking and studying patterns with what they contain in terms of numbers, shapes, and symbols (Al-Huwaidi, 2006) as it focuses on mental habits, thinking skills, practicing mental habits, and dealing with logic, contradictions, and reasoning (Joudeh \& Al-Aker, 2018). It also affects how individuals understand problems, develop hypotheses, tests them, and develop appropriate solutions (Valverde et al., 2002). Mathematics curricula have an essential value in real life, whether in mathematical operations, geometry, algebra, statistics, probabilities, etc. (Even, 2020), as they contain many topics that have been used in life situations (Park \& Leung, 2006).

As for science curricula and methods of teaching them, they have received great attention in various countries of the world due to the increase in challenges that affected the philosophy of designing science curricula, the growth of scientific knowledge and the increase of its relationship with issues of society, the environment, science, technology and economics, and the escalation of environmental problems and technological development. Therefore, educational systems have responded to the requirements of change and development in science education curricula from focusing on memorization and indoctrination to acquiring science, thinking, and problem-solving skills (Ragheb, 2014). As for science education, there is an emphasis on strategy as well as practical activities and experiences with student participation, especially in early education stages (Haeusler \& Donovan, 2020). The school curricula must be compatible with modern educational philosophy in terms of respecting the learner's personality, developing his intelligence and abilities, and encouraging him to think logically and scientifically, and consider individual differences and the psychological needs of learners (Hassan, 2012). This is done in light of the knowledge base that determines the appropriate type of knowledge for learners and the method for presenting it to them (Bin Qasim, 2018).

Collins curriculum in its philosophy follows the Socratic Method customized and adapted for use in elementary schools. First, it is represented in selecting materials with abstract content to challenge students' logic, which leads to different meanings for each student to encourage him to have an idea of discussion. This is done in particular to teach children how to think. After that, the teacher must read the material since if he is not familiar with it, he will not explain or teach it (Zach, 1997). After that, the individual begins to ask a series of related questions, starting with referring to the title and then the topic covered by the lesson. Expectations must be based on the use of logic, reason, and evidence to help students build a theory or a set of principles; the teacher poses questions at points relevant to the topic, and thus, students learn how to test their reasoning and way of thinking (Collins \& Tamarkin, 1990). Students write essays on their critical and analytical opinions. The learner learns how to refer to what was previously learned to support his opinions and ideas (Montgomery, 2011).

In the Socratic Method, the teacher controls the rate of information conveyed to the students so that it is organized to encourage students to participate actively and learn self-control (Gimson, 2009). Collin curriculum, in particular, avoids occupying students with too much homework but with emphasis on experience and reflection (Collins \& Tamarkin, 1990; Collins, 1989).

Many curriculum experts believe that Collins curriculum is not suitable for teaching in Jordanian schools for many reasons, including that it does not adhere to the philosophy of education 
that is based on many foundations, including love and pride in the homeland. And that Islam recommends the necessity of knowledge and the provision of the righteous values and principles that constitute the conscience of the individual and the group from the Education Law No. (3) of 1994 and its amendments. And Collins textbooks for schools in some districts and schools in the Kingdom of Jordan were not based on any national study or recommendations document showing the reasons for the development of the curriculum and its foundations, and the national vision of reform and education in changing the curriculum according to local needs, national experience, and global trends. These books did not adhere to the philosophy of education. As that the curricula Collins replaced did not exceed four years of application and were based on a lofty vision, and were reviewed and revised before their trial. The development of Collins curriculum was not based on writing and translating books prepared by the National Curriculum Centre into a global or national study, or any document proving that the previous curricula are not appropriate to the needs of Jordanian society and students' abilities or that they do not keep pace with global trends. And these books did not take the right of time and effort in checking and reviewing the curricula by those who were involved in this curriculum because the concerned committee must study any draft or any book to audit the books and translation and put the necessary notes on it (https://www.aredaonline.com/246121).

The decision to approve the teaching of mathematics and science books of Collins curriculum in the Jordanian schools is considered a transgression of educational norms, as it did not give a measure of the study, scrutiny and amendment within the ministry's committees and specialists. And it did not take into account the study of the curriculum by the specialized committees for the study and its approval, and the teaching of Collins curriculum continues to be a subject of societal, educational controversy even though its teaching has already started in the academic year 2019/2020 (AlKhashinah, 2019).

Salah and Goifel (2021) stated that with the issuance of Collins curriculum, protests, criticisms, and campaigns appeared on social media calling for the cancellation of its teaching in the Jordanian schools due to the difficulty of its teaching and that its level is higher than the classes assigned to it, which impedes the educational, scientific process and creates an atmosphere of anxiety among teachers, students and parents as well (Salah \& Goifel, 2021). Also, Sheikh (2019) stated that returning to the national curriculum is better, at least until appropriate adjustments are made to Collins curriculum to suit Jordan's educational and social environment.

Teachers form an essential and important link between the curriculum and the learner, being the party responsible for implementing the curriculum and instilling it in the minds of learners. They are also the most familiar with the characteristics of their students and the most sensitive to the educational environment; therefore, they can judge the quality of the curriculum and its suitability for learners and educational fulfilment. The decision to teach Collins curriculum (science and mathematics) for the first and fourth grades in the Jordanian schools came quickly and suddenly (AlSheikh, 2019). There were many reactions to this decision, through the work of researchers in the educational field and as a result of their field visits to several primary schools. Through the researchers' meetings with many teachers, they noticed complaints from teachers about teaching Collins curriculum in mathematics and science for the first and fourth grades, so this study came to answer the following questions:

1. What is the degree of satisfaction of teachers in basic schools of Amman Directorate of Education with teaching Collins curriculum?

2. Are there statistically significant differences at the level of significance $(\alpha \leq 0.05)$ in the degree of teachers' satisfaction with Collins curriculum due to the variables gender and years of experience? 
The current study sought to:

1. Identify the degree of teacher's satisfaction in Amman Directorate of Education basic schools with teaching Collins curriculum.

2. Identify the differences between the responses of the study sample in the degree of teachers' satisfaction with Collins curriculum due to the difference of the variables gender and years of experience.

\subsection{The Importance of the Study}

The study aims to shed light on teachers' satisfaction with Collins's developed curricula. It aims to achieve educational reform and development that is consistent with the Jordan education philosophy and objectives, in a way that is fundamentally consistent with the interest of students, and provide them with all means of success by employing the skills of the twenty-first century, such as critical and creative thinking, research, investigation and teamwork, exploration, analysis and verification, depending on modern strategies and methods of learning, the optimal use of what is provided by the learning environment and its relevance to the learner's life, identity and environment. This study gains its importance from the fact that it contributes to adding information to the Arab and research literature with information about Collins's curricula. Studies that dealt with Collins curricula in the Arab world within the limits of researchers' knowledge are rare The study also seeks to provide interested people and specialists with information to develop information about the developed curricula that would contribute to educational reform. It is hoped that this study will assist those involved in curriculum development as part of planning for implementing curriculum development for other stages.

\subsection{Limitations of the Study}

The current study has some limitations:

Spatial limits: The study was restricted to the First and Second Amman Directorate of Education.

Temporal boundaries: The study was conducted in the year 2020 .

Human Limits: The study sample was restricted to a sample of teachers in the First and Second Amman Education Directorate.

Objective boundaries: The objective of the study was restricted to identifying the teachers' level of satisfaction with Collins curriculum.

\subsection{Terminology of Study}

The current study dealt with the following procedural definitions:

Collins curriculum: The mathematics and science curricula for the first and second basic grades which have been approved for teaching in the Jordanian schools since the academic year 2019/2020.

Satisfaction: It is the individual's attainment of a goal, which follows the fulfilment of needs and the fulfilment of desires and aspirations, and with it the individual is more productive and more positive (Muhammad, 2018). In this study, it is defined procedurally as the overall degree of responses of the study sample on the scale of counting for that.

\section{Literature Review}

Herold (2020) studied how physical education teachers in England interpret and implement the new 
and traditional national curriculum for physical education. The sample consisted of (43) teachers. The data were collected semi-structured interviews. The static comparison method was used to develop essential topics through the data analysis process. The results indicated that the simple nature of the curriculum document has provided teachers with restricted guidance for teaching and valuation. The removal of specific evaluation guidelines allowed curriculum freedom; however, opportunities had not been seized to implement innovative evaluation methodologies. The messages of the competitive curriculum were noticed, but the teachers saw no need to act because of it. The study concluded that recent curriculum reform is unlikely to have a significant impact on current teaching in England, where curricular stagnation and different practices are likely to have consequences in the medium term.

Al-Taie (2019) examined the negative effects of changing the mathematics curriculum for elementary stage from the point of view of mathematics teachers in Iraq. The researcher used the descriptive approach, and the sample was randomly selected, amounting to 50 female mathematics teachers in Babil Governorate Centre for the academic year 2018/2019. A questionnaire consisting of three domains was used, and after conducting a statistical analysis of the test items, the results showed a set of negative effects to change the mathematics curriculum. In light of the research results, the researcher recommended the necessity of reconsideration by the authors of the Iraqi curriculum for the primary school mathematics curriculum and the need to take into account the opinions of mathematics teachers to improve the content of the curriculum.

Butt and Shahzad (2019) explored the challenges facing the English language teachers in secondary schools to implement change in the national curriculum (2006) in Punjab, Pakistan. The study was prepared during the period of implementing the change in the secondary school of the National Curriculum for English (2006), and case studies were produced for four schools. Data were collected through a one-on-one technique for secondary school English language teachers, headmasters of schools, education authority officials, provincial curricula and professional development representatives. The results revealed that teachers were seldom consulted during the planning or designing phase of curriculum change, and there was no formal support available for teachers at the district or school level to prepare them to implement the curriculum change. The absence of appropriate environmental conditions in schools and the teachers agency's weakness led to the emergence of many challenges for teachers in implementing the new curriculum successfully. The results led to recommendations that county governments should develop support mechanisms and professional development activities to strengthen teachers agency to ensure curriculum change successfully.

Al-Lazam (2019) investigated the teaching problems facing teachers of science curricula developed in the middle stage in Riyadh. The study sample consisted of (152) teachers. The descriptive approach was used to analyse the data. The data collection tool was a survey. The descriptive approach was used to analyse the data. The results of the study revealed problems related to the students which came in the first place with a high degree, followed by problems related to the science factor in the second place with a high degree, while problems related to the content ranked last with an average rank. As for the overall average of the problems, it was of a medium degree, and there were no statistically significant differences between the averages of all problems entirely due to the variable of specialization, except for the problems related to the teacher, the student, and the evaluation, and there were differences in favour of biology teachers. As for the scientific qualification variable, there are no differences except for problems related to learning resources, educational activities and evaluation in favour of holders of educational qualification, and the qualification type variable revealed the absence of differences except for problems related to the teachers in favour of holders of a master's qualification. There are no differences in the experience variable except for problems related to the teachers, educational objectives, and content, for the benefit of the study sample according to the variable number of years of experience. For the training courses variable, there are no differences except for problems related to the teachers and evaluation, whereas it was for the benefit of the study sample individuals who received training courses in the developed science 
curricula.

Al-Shammari and Al-Dawish (2017) studied problems of teaching mathematics course at the elementary level in remote schools in the Hail region in Saud Arabia. They used the descriptive survey approach. The study sample consisted of (102) mathematics teachers at the primary level in remote schools, and (11) educational supervisors for mathematics. A questionnaire was used was used to collect data. It included five domains: problems related to the course, problems related to the students, problems related to the mathematics teachers, problems related to the mathematics supervisors and problems related to the school administration. The results revealed inadequacy of the general goals of the students' age and the absence of statistically significant differences in all the problems related to teaching the mathematics course at the elementary level according to the different variable of grades taught by teachers. The results also that there are statistically significant differences between members of the study sample of elementary school teachers' views towards all problems related to teaching the mathematics course at the primary stage in remote schools in the region of Hail for the benefit of the study sample members of mathematics teachers in primary schools Besides, they showed that there were no statistically significant differences between members of the study sample of elementary school teachers towards all problems related to teaching the mathematics course.

Muhammad (2015) examined the trends of kindergarten teachers towards the new curriculum (My right to play, learn and innovate) and the role of some variables such as academic qualification, experience, training courses and the educational region in Fayoum Governorate in Egypt. A random stratified sample was selected consisting of (350) teachers. To achieve the objectives of the study, a questionnaire was designed, and its validity and reliability were ascertained. After applying the study and collecting data, a statistical treatment was carried out. The results showed that there were high positive trends towards the new approach in general.

Al-Sheikh's (2016) study aimed to identify the problems and the differences between the participants' responses to these problems in teaching the optimal science curriculum (McGraw-Hill series) as seen by supervisors and teachers working in Al-Kharj Intermediate Schools for Girls in the Kingdom of Saudi Arabia. The descriptive approach was used, and a survey 81 items classified into 7 categories (teacher, book, teaching methods, aids, students, assessment, school administration and teacher's guide). The sample of the study consisted of (88) participants (7 supervisors and 81 teachers). The results revealed statistically significant differences between the supervisors' answers and the teachers' answers. The supervisors agreed that the science education curriculum is a big problem, with major concerns regarding teachers who were at the top of the list, followed by teaching methods, aids, laboratories, assessment, and the school administration in the last position. The teachers' responses showed that the level of problems they face when teaching science is average. The concerns came in the following order: book, school administration, students and evaluation. The study recommended that teachers should be systematically provided with professional training programs, including constructive assessment to perform their work efficiently.

\section{Methodology and Procedures}

\subsection{Study Population}

The population of the study included all teachers in the First and Second Amman Education Directorate, whose number is (3199) male and female teachers (Ministry of Education statistics, 2020).

\subsection{The Study Sample}

The study sample consisted of (450) male and female teachers from the First and Second Amman Education Directorate who were chosen in a simple random way with a percentage (14\%) of the study 
population. The study tool was distributed electronically. Table (1) shows the distribution of the study sample according to the variables (gender, years of experience).

Table 1: Distribution of the study sample according to the gender and years of experience variables

\begin{tabular}{llcc} 
Variable & Category & Repetition & Percentage \\
\hline Gender & Male & 142 & 31.6 \\
& Female & 308 & 68.4 \\
Years of Experience & Total & 450 & 100.0 \\
& Less than five years & 100 & 22.2 \\
& From 5-10 years & 138 & 30.7 \\
& $11-15$ years old & 112 & 24.9 \\
& 16 years and over & 100 & 22.2 \\
& Total & 450 & 100.0
\end{tabular}

Table (1) shows the following:

- Regarding the gender variable: the number of males reached (142) with a percentage of (31.6\%), while the number of females reached (308) with a percentage of (68.4\%).

- $\quad$ Regarding the years of experience variable: the number of respondents from the category of fewer than five years reached (100) with a percentage of $(22.2 \%)$, the number of respondents from 5-10 years reached (138) with a percentage of (30.7\%), and the number of respondents from $11-15$ years reached (112) with a percentage of $(24.9 \%)$, and the number of respondents in the category of 16 years and overreached (100) with a percentage of $(22.2 \%)$.

\subsection{The Study Tool}

A questionnaire was constructed to collect data from the study sample based on previous studies (AlSheikh, 2016; Al-Shammari \& Al-Dawish, 2017; Al-Taie, 2019). It consisted of personal information of the members of the study sample (gender and years of experience). It also included (15) items that measure teachers' level of satisfaction with Collins curriculum from the teachers' point of view. A descriptive survey method was used as it suits the nature of the study and its objectives.

\subsection{The Validity of the Questionnaire}

Validity of the content of the questionnaire was verified by presenting it to (8) arbitrators who are specialized in teaching and education curricula. They were asked to express their opinion on the soundness of the linguistic wording of the paragraphs, its clarity in terms of meaning, and its measurement for the purpose for which it was set for, and any observations or amendments they consider fitting. The arbitrators' notes and propositions were considered, and the items of the questionnaire were revised based on the consent of the arbitrators to come at the questionnaire final form.

To extract the indications of constructive validity for all items of the questionnaire, it was piloted to a sample consisting of (25) teachers, out of the study real sample, the coefficients between each item of the questionnaire were calculated and the questionnaire as a whole as illustrated in Table (2).

Table 2: Correlation coefficients between each paragraph and the questionnaire as a whole

\begin{tabular}{cccccc} 
No & $\begin{array}{c}\text { Correlation with the } \\
\text { questionnaire }\end{array}$ & No. & $\begin{array}{c}\text { Correlation with the } \\
\text { questionnaire }\end{array}$ & $\begin{array}{c}\text { No. } \\
\begin{array}{c}\text { Correlation with the } \\
\text { questionnaire }\end{array}\end{array}$ \\
\hline $\mathbf{1}$ & $0.58^{* *}$ & 6 & $0.76^{* *}$ & 11 & $0.56^{* *}$ \\
2 & $0.54^{* *}$ & 7 & $0.65^{* *}$ & 12 & $0.65^{* *}$ \\
& & 228 & &
\end{tabular}




\begin{tabular}{cccccc} 
No & $\begin{array}{c}\text { Correlation with the } \\
\text { questionnaire }\end{array}$ & No. & $\begin{array}{c}\text { Correlation with the } \\
\text { questionnaire }\end{array}$ & No. & $\begin{array}{c}\text { Correlation with the } \\
\text { questionnaire }\end{array}$ \\
\hline 3 & $0.61^{* *}$ & 8 & $0.69^{* *}$ & 13 & $0.75^{* *}$ \\
4 & $0.63^{* *}$ & 9 & $0.79^{* *}$ & 14 & $0.79^{* *}$ \\
5 & $0.52^{* *}$ & 10 & $0.80^{* *}$ & 15 & $0.87^{* *}$ \\
\hline
\end{tabular}

${ }^{*}$ Function correlation coefficients at the significance level $(\alpha \leq 0.05)$

${ }^{* *}$ Function correlation coefficients at the significance level $(\alpha \leq 0.01)$.

Table (2) displayed that the correlation coefficients between each item and the questionnaire as a whole ranged between (0.54-0.87), which are considered significant and acceptable correlation coefficients to apply this study.

\subsection{The Reliability of the Questionnaire}

To ensure the indicators of the reliability of the questionnaire, it was applied to an exploratory sample consisting of (25) male and female teachers who were selected from outside the study sample. Cronbach Alpha equation was calculated for the study's questionnaire, to extract the internal consistency. The results showed that the reliability coefficient of the Cronbach Alpha method for the questionnaire of the degree of teachers' satisfaction with Collins curriculum reached (o.8o). This value indicates a high and acceptable degree to apply the study.

\subsection{Correcting the Study Tool}

The study tool included a questionnaire on the degree of satisfaction of teachers in the basic schools of the Amman Directorate of Education with Collins curriculum. It consisted of (15) paragraphs, where the researcher used Likert scale of five-point gradient to measure the study sample members' opinions where they were given a very large extent, to a large extent, to a medium extent, to a small extent, to a very small extent 5,4,3,2,1 respectively. The following classification was followed to judge the averages:

- From 1.00- 2.33 as low

- $\quad$ From $2.34-3.67$ average

- $\quad$ From 3.68 - 5.00 high

\subsection{The Study Variables}

- Independent variables: Gender and it has two categories: (male and female). Years of experience which has four levels: (less than five years, 5-10 years, $11-15$ years, 16 years, and more).

- Dependent variable: The degree of teachers' satisfaction with Collins curriculum in Amman Directorate of Education

\subsection{Statistical Analysis and Treatment Methods}

Since the appropriate method of analysis depends mainly on the type of data to be analysed, several statistical methods have been relied upon through using the Statistical Package for Social Sciences (SPSS) program. In light of the nature of the study variables, measurement methods, and the purposes of the analysis, the following statistical methods were used:

- $\quad$ Frequencies and percentages of the sample population distribution among the study variables.

- Cronbach Alpha to extract the reliability of study tools.

- $\quad$ Descriptive statistics: the means and standard deviations of the two study measures.

- The binary analysis of variance (2-way ANOVA) test was applied to detect differences in the degree of teachers' satisfaction with Collins curriculum, according to two variables, namely, gender and years of experience. 


\section{Results and Discussion}

This part includes a presentation and discussion of the study results, which aims to examine the degree of teachers' satisfaction with Collins curriculum from the teachers' perspective in Amman Directorate of Education in Basic schools. The results of this study are presented according to the study questions.

RQ1. What is the degree of satisfaction of teachers in the basic schools of the Amman Directorate of Education with Collins curriculum?

To answer this question, averages and standard deviations were extracted for all items of the scale of "Teachers' Satisfaction in Basic Schools of the Amman Directorate of Education with Collins Curriculum" average of the scale as a whole. Table (3) illustrates this:

Table 3: The averages and standard deviations for all items of teachers' satisfaction in the basic schools of Amman Directorate of Education about Collins curriculum and the scale as a whole $(\mathrm{n}=$ 450)

No. Paragraph

Arithmetic Standard average deviation

Degree Rank

5 Collins curriculum goals align with both general and specific primary education goals

\begin{tabular}{llll}
3.60 & 1.02 & Average & 1 \\
3.56 & 0.95 & Average & 2 \\
3.54 & 1.08 & Average & 3 \\
3.53 & 1.05 & Average & 4 \\
3.39 & 0.67 & Average & 5 \\
3.37 & 0.61 & Average & 6 \\
3.36 & 1.14 & Average & 7 \\
3.35 & 0.75 & Average & 8 \\
3.35 & 1.16 & Average & 9 \\
3.31 & 0.65 & Average & 10 \\
3.26 & 0.59 & Average & 11 \\
3.25 & 1.18 & Average & 12 \\
2.24 & 1.14 & Low & 13 \\
2.11 & 1.16 & Low & 14 \\
2.08 & 1.20 & Low & 15 \\
\hline 3.15 & 0.41 & Average &
\end{tabular}

9 Collins curriculum content correlates with mathematics learning objectives

7 Collins curriculum is easy to train teachers with

4 Collins curriculum encourages processes of analysis, synthesis and innovation with appropriate teaching methods

12 The content of Collins curriculum is explicit and easy to understand

13 Collins curriculum content is sensitive to individual differences

6 Lesson titles in Collins' curriculum are relevant to the content

11 Collins curriculum goals are progressive in their construction

problemsolving skills

14 I feel comfortable teaching Collins curriculum

15 Collins curriculum promotes national unity and good citizenship

2 Collins curriculum stems from the needs of the learner, community and knowledge alike

10 The images and graphics in Collins curriculum are linked to the local environment

8 Collins curriculum content is proportional to the length of time available to teach well during the semester

1 I prefer Collins curriculum over the previous ones Scale as a whole (teachers' satisfaction with Collins curriculum)

Table (3) shows that the averages for the items of teachers' satisfaction with Collins curriculum ranged between (2.08-3.60) with low and medium approval scores, where the top of it was for paragraph No. (5) which states "Collins curriculum goals are consistent with general and special education goals for the primary stage" with a standard deviation (1.02), followed by the average (3.56) for paragraph No. (9) which states "The content of Collins curriculum is related to the objectives of 
learning mathematics" and with a deviation standard (0.95). Then it is followed by the average (3.54) for paragraph No. (7) which states "Collins curriculum is easy to train teachers on" with a standard deviation (1.08), while the lowest was for paragraph No. (1) "I prefer Collins curriculum over the previous curricula" and with a standard deviation (1.20). The observations and feedback regarding the curricula were not taken into account, and they were full of information and inappropriate for the target age group. Many teachers see it as contrary to Jordanian customs and traditions, as the school curricula constitute a large percentage of the student's identity and personality. The curriculum has violated the inference process, which is a prerequisite for building the concepts of the child in the cognitive construct. It separates learning from the developmental growth of the child and costs him something that cannot tolerate his abilities and what is not in harmony with himself. This is what led most teachers to make summaries of the subjects of science and mathematics for the students to understand them more easily and faster. This added effort to teachers in education. This is what AlTai (2015) pointed out in his study that changing the mathematics curriculum for the elementary stage from the teachers' point of view has negative effects. The results of the current study are also in agreement with the findings of Al-Shammari and Al-Dawish's (2017) study which showed that the general objectives of the mathematics course in the elementary stage were not appropriate for the age of the students. At the same time, the results of the current study differed from the result of Muhammad's (2015) study which showed high positive trends towards the new curriculum in general.

RQ2. Are there statistically significant differences at the level of significance $(\alpha \leq 0.05)$ in the degree of teachers' satisfaction with Collins curriculum due to the two variables, gender and years of experience?

To answer this question, the 2-Way ANOVA test was applied to detect differences in the degree of teacher satisfaction with Collins curriculum according to the gender, and years of experience variables.

Table 4: The averages and standard deviations of the degree of teachers' satisfaction with Collins curriculum according to gender variables and years of experience $(n=450)$

\begin{tabular}{llcc} 
Variable & Category & Arithmetic Average & Standard Deviation \\
\hline Gender & Male & 3.10 & 0.45 \\
Years of Experience & Female & 3.18 & 0.39 \\
& Less than five years & 3.18 & 0.37 \\
& From 5-10 years & 3.29 & 0.40 \\
& 11-15 years old & 3.09 & 0.46 \\
& 16 years and over & 3.00 & 0.34
\end{tabular}

Table (4) shows the presence of obvious differences between the averages according to the difference between the sex variables and the years of experience. To find the statistical significance of these differences, the two-way analysis of variance (Way ANOVA-2) was applied to the two measures of the study as illustrated in Table (5).

Table 5: Results of the 2-Way-ANOVA analysis to reveal differences in the degree of teachers' satisfaction with Collins curriculum according to gender and years of experience variables

\begin{tabular}{llllll}
$\begin{array}{l}\text { The source of } \\
\text { variance/variable }\end{array}$ & $\begin{array}{l}\text { Sum of } \\
\text { squares }\end{array}$ & $\begin{array}{l}\text { Degrees of } \\
\text { freedom }\end{array}$ & $\begin{array}{l}\text { Average of } \\
\text { squares }\end{array}$ & F & Statisticalsignificance \\
\hline Gender & .102 & 1 & .102 & .641 & .424 \\
\hline Years of Experience & 5.001 & 3 & 1.667 & 10.512 .000 \\
\hline Error & 70.575 & 445 & .159 & & \\
\hline
\end{tabular}

Total Corrected

$76.077 \quad 449$


Table (5) shows there were no statistically significant differences at the level of significance ( $\alpha \leq 0.05)$ in teachers' satisfaction with Collins curriculum according to the variable of sex, as the value of $(F)$ was (.641) and in statistical significance (.424). This result indicates the convergence of views of the study sample members of male and female teachers on their dissatisfaction with Collins curriculum due to the difficulty they face in teaching this curriculum because it does not correspond to the students' level, as the curriculum violates the process of inference, which is a prerequisite for building the concepts of children in the cognitive construction. Table (5) shows the presence of statistically significant differences at the level of significance $(\alpha \leq 0.05)$ in teachers' satisfaction with Collins curriculum according to the years of experience variable, where the value (F) was (10.512) and with statistically significant of (.ooo). To reveal the sites of differences, Scheffe test was applied as illustrated in Table (6).

Table 6: Scheffe test results to reveal the sites of differences in the degree of teachers' satisfaction with Collins curriculum according to the years of experience variable

\begin{tabular}{|c|c|c|c|c|c|c|c|}
\hline Scale & $\begin{array}{l}\text { Years of Experience } \\
\text { category }\end{array}$ & No. & average & $\begin{array}{l}\text { Less than } \\
\text { five years }\end{array}$ & $\begin{array}{c}\text { From 5-10 } \\
\text { years }\end{array}$ & $\begin{array}{c}\text { From 11-15 } \\
\text { years }\end{array}$ & $\begin{array}{l}16 \text { years } \\
\text { and over }\end{array}$ \\
\hline \multirow{4}{*}{$\begin{array}{l}\text { Degree of } \\
\text { teacher } \\
\text { satisfaction } \\
\text { with Collins } \\
\text { curriculum }\end{array}$} & \multirow{4}{*}{$\begin{array}{l}\text { Less than five years } \\
\text { From } 5 \text {-10 years } \\
\text { From } 11-15 \text { years } \\
16 \text { years and over }\end{array}$} & 100 & 3.18 & \multirow[t]{4}{*}{ - } & -0.11 & 0.09 & 0.18 \\
\hline & & 138 & 3.29 & & - & $0.20^{*}$ & $0.29^{*}$ \\
\hline & & 112 & 3.09 & & & - & 0.09 \\
\hline & & 100 & 3.00 & & & & - \\
\hline
\end{tabular}

Table (6) shows that the differences in the degree of teachers' satisfaction with Collins curriculum according to the years of experience variable between the two categories (from 5-10 years, 16 years and more) were in favor of the "5-10 years" category with average of (3.29). While the average for the category "16 years and over" was (3.0o). Differences also appeared between the two categories "from 5-10 years" and "11-15 years", and the differences were in favor of the "5-10 years" category, where the arithmetic mean of the "11-15 years" category was (3.09). There were no statistically significant differences between the other groups. This result is attributed to the fact that most teachers with average experience (5-10 years) are more likely to adjust and have greater motivation for change than teachers who have more experience. They were in harmony with the regulations, guidelines, and instructions for ready-made curricula to be presented to students without a critical look or seeking to develop and amend curricula. This result differed with the findings of the Al-Zamam's (2019) study which showed no differences in the teaching problems facing teachers of science curricula developed in the intermediate stage in Riyadh, according to the variable of experience.

\section{Conclusion}

The results showed that there were statistically significant differences at the significance level $(\alpha \leq 0.05)$ in the scale of "teachers' satisfaction with the Collins curriculum" according to the variable "years of experience" in favor of the experience category (5-10 years), while there were no differences in the teachers' satisfaction scale with "Collins Curriculum" due to gender variable. This indicated that the process of developing and amending school curricula is a positive phenomenon and a crucial requirement in response to local or global social changes. The process of curricula development and amendment should be conducted in order to solve a problem that requires progress and correction and to get rid of the shortcomings that exist in the currently applied curricula. Therefore, this research views that there is a necessity of involving teachers and eliciting their opinions to conduct any curricula development and training them on the curriculum intended to be progressed. Consequently, the developed curriculum should be subjected to preliminary evaluations and be compatible with the cultural environment of the community of the targeted population before it is generalized to all schools. 


\section{Recommendations}

In light of the findings from this study, the following recommendations can be made:

- Involving male and female teachers in curriculum development proposals and their views should be read and considered.

- $\quad$ Revising and developing Collins curriculum as much as possible in science and mathematics subjects to be in line with the norms of the Jordanian society. And working to merge them with the previous courses, rather than cancelling them completely.

- Conducting studies similar to the current study in different schools across the Hashemite Kingdom of Jordan, taking into account other variables such as grade, teachers' ages or educational qualifications.

\section{References}

Al-Huwaidi, Z. (2006). Methods and strategies of teaching mathematics. Jordan, University Book House.

Al-Khashashna, A. (2019). Reading in Collins science and mathematics curriculum - popular rejection and government slowdown. Amman: Zad Jordan News Agency. www.jordanzad.com.

Al-Khouli, M. (2011). Curriculum: Foundations, design, development and evaluation. Amman: Dar Al-Falah for Publishing and Distribution.

Al-Shammari, H. \& Al-Dawish, S. (2017). Problems of Teaching Mathematics Course at Elementary Stage in Remote Schools in the Hail Region from the Viewpoint of Teachers and Educational Supervisors, The Scientific Journal of the Faculty of Education: Assiut University, 33(2), 383-424.

Al-Taie, I. (2019). The negative effects of changing mathematics curricula for the elementary stage from the viewpoint of mathematics teachers. Journal of Babylon University for Human Sciences, 27(6), 353-364.

Alzam, I. (2019). Problems of teaching science curricula developed in middle school from the viewpoint of its teachers in Riyadh. The International Journal of Specialized Education, 8(1), 1-17.

Barika, N. (2008). Evaluation of the effectiveness of the Palestinian mathematics curriculum for the eleventh grade, literary section. (Unpublished master's thesis, Islamic University, Gaza, Palestine).

Bin Qasim, W. (2018). Curricula in light of global climates. Jordan: Dar Al-Shukry for Publishing.

Butt, M., \& Shahzad, A. (2019). The agency of secondary school English teachers and national curriculum change (2006) in Pakistan: Challenges and problems. Journal of Research, 13(1), 134-147.

Collins, M. (1989). The Marva Collins Method; a Manual for Educating and Motivating Your Child. Westside Preparatory School. https://eric.ed.gov/?id=ED328629

Even, R. (2020). Mathematics teachers edit textbooks: Opportunities and challenges. STEM Teachers and Teaching in the Digital Era, 37-52. Cham: Springer.

Gimson, A. (Ed.). (2009). Taking advantage of e-learning's new tricks: But do they work for old dogs, too?. Development and Learning in Organizations: An International Journal, 23(4), 34-36. https://www.emerald.com/insight/content/doi/10.1108/14777 280910 970792/ full/html

Haeusler, C., \& Donovan, J. (2020). Challenging the science curriculum paradigm: Teaching primary children atomic-molecular theory. Research in Science Education, 50(1), 23-52. https://link.springer.com/article/10.1007/s11165-017-9679-2

Hassan, S. (2012). Curriculum development: A contemporary vision: Curriculum, curriculum development, curriculum software design and software models, curriculum quality standards. Arab Group for Training and Publishing.

Herold, F. (2020). 'There is new wording, but there is no real change in what we deliver': Implementing the new National Curriculum for Physical Education in England. European Physical Education Review, 26(4), 920937. https://journals. sagepub. com/doi/abs/10.1177/1356336X19892649

Hollins, E. R. (1982). The Marva Collins story revisited: Implications for regular classroom instruction. Journal of Teacher Education, 33(1), 37-40. https://journals.sagepub. com/doi/pdf/10.1177/002248718203300108

Joudeh, M. \& Al-Aker, M. (2018). The level of effective mathematics curriculum standards and its relationship to the productive habits of mind among high school students in Gaza, Al-Manara, 24(4), 369-401.

Lockhart, Z. (2019). Mutual vulnerability and intergenerational healing: Black women HBCU students writing memoir. Journal of Poetry $\quad$ Therapy, 32(3), 169-180. https://www.tandfonline.com/doi/abs/10.1080/o8893675.2019.1625156

Mohammed, M. (2018). Job satisfaction and its impact on developing performance. Amman: Ibn Al-Nafees Publishing House. 
Montgomery, S. E. (2011). Marva Collins' method: providing culturally relevant pedagogy. Vitae Scholasticae, 28(2), 34-51. https://go.gale.com/ps/i.do?id=GALE\%7CA326657939\&sid

Muhammad, S. (2015). Attitudes of kindergarten teachers towards the new curriculum (My right to play and create). Arab Childhood Journal (63), 69-92.

Park, K., \& Leung, F. K. (2006). A comparative study of China, England, Japan, Korea, and the United States. In F. S. Leung, K.-D. Graf \& F. Lopez-Real (Eds.), Mathematics education in the different cultural traditions-A comparative study of East Asia and the West (Vol. 9), (pp. 227-238). Germany: Springer

Ragheb, M. (2014). Analysis of the level and questions of the science book for the sixth grade from the point of view of science teachers for the basic stage. (Unpublished master's thesis, University of Jordan, Jordan).

Salah, S. M., \& Goifel, M. (2021). Evaluation of the developed science curriculum (Collins) for the fourth grade from the point of view of teachers and supervisors in Ma'an Governorate. Middle East Journal of Humanities and Cultural Sciences, 1(1), 128-110.

Sheikh, A. (2016). The problems of teaching science curricula developed in the middle stage from the teachers' and supervisors' perspectives in Al-Kharj Governorate. Taibah University Journal for Educational Sciences, 2(11), $261-277$.

Sheikh, G. (2019). "Collins Curriculum" ... Calls for a return to old books, voice of the silent majority. Ammon, Amman. www.ammonnews.net.

Spurts, A. (2019). Controversial school curricula in Jordan. Al-Araby Al-Jadeed website, Amman www.alaraby.co.uk.

The Ministry of Education (2017). Science for the fourth grade basic. The Hashemite Kingdom of Jordan: Curriculum Department, Textbooks.

Valverde, G. A., Bianchi, L. J., Wolfe, R. G., Schmidt, W. H., \& Houang, R. T. (2002). According to the book: Using TIMSS to investigate the translation of policy into practice through the world of textbooks. Springer Science \& Business Media.

Zach, K. K. (1997). A return to literacy: Incorporating classics into the reading curriculum. American secondary education, 25(3), 19-22. https://www.jstor.org/stable/ 41064204

Zhu, Y., \& Fan, L. (2006). Focus on the representation of problem types in intended curriculum: A comparison of selected mathematics textbooks from Mainland China and the United States. International Journal of Science and Mathematics Education, 4(4), 609-626. https://link.springer.com/article/10.1007/s10763-0o69036-9 